Original Research Paper

\title{
Characterization of the Changes in Opened Sufu Bottles During Storage with Mathematical Model
}

\author{
${ }^{1,2}$ JingJing Liang, ${ }^{2}$ Dawei Li, ${ }^{2}$ Ruiqin Shi, ${ }^{2}$ Jie Wang, ${ }^{2,3}$ Yanli Ma and ${ }^{1}$ Ke Xiong \\ ${ }^{I}$ Beijing Advanced Innovation Center for Food Nutrition and Human Health, \\ Beijing Technology and Business University, Beijing, 100048, China \\ ${ }^{2}$ College of Food Science and Technology, Hebei Agricultural University, Hebei, 071000, China \\ ${ }^{3}$ Henan Key Laboratory of Industrial Microbial Resources and Fermentation Technology, \\ Nanyang Institute of Technology, Nanyang, 473000, China
}

Article history

Received: 11-10-2018

Revised: 25-11-2018

Accepted: 11-12-2018

Corresponding Author:

Yanli Ma

College of Food Science and

Technology, Hebei

Agricultural University, Hebei, 071000, China

Email: carinaljj@126.com

\begin{abstract}
Artificial Neural Network (ANN) is a type of nonlinear empirical model, which can clarify the complex relation between the inputs and outputs that allows it to approximate any nonlinear function for making predictions. The objective of this study is to monitor the Biogenic Amines (BAs) content and selected physicochemical properties of sufu (a traditional Chinese fermented soybean product) along time. Simultaneously, based on initial values, a grey model and an ANN were developed to predict the influence of storage process parameters on the quality changes during storage. Results revealed that the total amounts of BAs in newly opened bottles of white, red and grey sufu were $419.61,311.52$ and $603.10 \mathrm{mg} \mathrm{kg}^{-1}$, respectively, no sufu samples posed the total biogenic amines tolerance level (over $1000 \mathrm{mg} \mathrm{kg}^{-1}$ ). Results showed that slight changes in the individual BAs were detected at $4^{\circ} \mathrm{C}, 15^{\circ} \mathrm{C}, 25^{\circ} \mathrm{C}$ and the formation of BAs was promoted at $35^{\circ} \mathrm{C}$ in grey sufu. Furthermore, grey model was developed with average relative errors within $\pm 7 \%$, the statistical parameters $\left(\mathrm{R}^{2}\right)$ of $\mathrm{pH}$, water activity and amino nitrogen was all above 0.90 . In the ANN, the number of neurons in the hidden layer was optimized, ten neurons revealed a positive correlation between the values obtained experimentally and those predicted values $\left(\mathrm{R}^{2}\right.$ $=0.99$ ). So ANN with highest $\mathrm{R}^{2}$ was selected to predict biogenic amines and our results demonstrated that grey sufu were not edible on the 25th days at $4{ }^{\circ} \mathrm{C}\left(\mathrm{BAs}>1000 \mathrm{mg} \mathrm{kg}^{-1}\right)$ and it would be better if white and red sufu are consumed within 40 days. We envision that our works can be used for proving a reference for consumers and offer new perspectives by mathematical model to avoid difficult, costly and time-consuming quality inspection, particularly in the field of storage.
\end{abstract}

Keywords: Biogenic Amines, Sufu, Storage Conditions, Grey Model, Artificial Neural Networks

\section{Introduction}

Sufu is a traditional fermented soy curd in China that is popular in oriental diets due to its unique flavor and rich nutrients. It has been consumed for more than 1000 years in China and is also called as Chinese cheese (Han et al., 2001). The manufacturing process of sufu varies in different regions of China, among which mold-fermented sufu is the most common type. The procedure for making mold-fermented sufu generally consists of four steps: Preparation of tofu via salt precipitation from boiled soymilk; preparation of pehtze through a pure culture bacterial fermentation; salting; and ripening in dressing mixture, which typically does not last for more than three months (Chao et al., 2008). During the manufacture and storage, the proteins are hydrolyzed to a range of intermediate-sized peptides, which are then hydrolyzed to shorter peptides and amino acids. Thus, proteolysis is the main biochemical event, the extent of which can change the flavor, texture and color of the sufu (Han et al., 2001). This process leads to the accumulation of free amino acids, 
some of which are the precursors of biogenic amines (Schirone et al., 2013).

BAs are organic, basic and low-molecular-weight nitrogenous compounds that are formed mainly by the decarboxylation of amino acids (Guan et al., 2013). Their presence in foods can cause varying degrees of harm to susceptible consumers, including headaches, vertigo and increased arterial blood pressure (Komprda et al., 2008; Elsanhoty and Ramadan, 2016). For this reason, the FDA also recommended that 1000 $\mathrm{mg} \mathrm{kg}^{-1}$ of total BA should be the tolerance level in fish (USFDA, 2001). The accumulation of BAs in fermented foods is a complex process affected by multiple factors and their interactions (Schirone et al., 2013). Also they are often used as good chemical indicators of products' hygienic quality. Sufu has been comprehensively examined throughout the different stages of its manufacture. The concentrations of BAs have also been determined in brines (Sun et al., 2010), tofu (Liang et al., 2013; Tripathi and Misra, 2005; Li et al., 2014) and postfermentation (Han et al., 2004). However, no one has studied the changes of biogenic amines during storage.

During storage, the microorganisms play a significant role, either directly by means of their metabolic activity, or indirectly via enzymes released into the sufu matrix. Given that sufu is consumed as a condiment which may be kept in opened bottles for quite a time, it is vulnerable to the microbial contamination in the environment, thereby affecting sufu quality and safety. For this reason, we aim to monitor the evolution of biogenic amines and physicochemical properties in sufu along time under different storage conditions and to our knowledge, it is the first report regarding focusing on the quality changes in an opened bottle. We envision that our works can be used for proving a reference for consumers about the preservation of sufu.

Grey predication Model (GM) is based on grey theory, which was developed for handling incomplete and rough datasets, this process is called grey prediction. The prediction is performed by solving an ordinary differential equation, which contains model coefficients being updated on line in order to characterize dynamic process. A grey prediction model was used to provide $\mathrm{pH}$ control that is widely used in the food industry (Chen et al., 2005; Chung et al., 2010). ARTIFICIAL NEURAL NETWORK (ANN) arises as a powerful and flexible tool with excellent predicting abilities, even when involving a complex systems. Artificial neural network is which is composed of three layers: The input layer links the network to the control variables, the hidden layer supplies the nonlinear functions for conversing input space to hidden space with high dimensionality, the output layer eventually provides the response of the input layer. As a more accurate alternative to predict, the use of ANN has notoriously increased in different scientific fields. Previous studies have shown the benefits of using ANN in prediction compared to other statistical methods. For instance, artificial neural network could be used to describe and predict the effects of temperature, $\mathrm{pH}$ and storage time on food microbiology (Fang et al., 2015; Lou and Nakai, 2000). Llave et al. (2012) applied ANN to predict cold spot temperature in retort sterilization of starch-based foods. ANN is applied for description of food quality changes during storage (Liu et al., 2015). However, there are few reports on the utilization of ANN for predicting quality of sufu during storage. Therefore, with separation of the initial values into training, validation and test sets as 70:15:15 ratios, the mathematical model was established to predict future quality in sufu.

In this research, we aim to contribute to improvement of the knowledge of quality changes in sufu for proving a reference for consumers about the preservation of sufu. Meanwhile based on experimental data, we develop linear modeling (through mathematical equations) and nonlinear modeling (with ANN) to predict the influence of storage process parameters on the Biogenic Amines (BAs) content and selected physicochemical properties of sufu, thus, the complex, costly and time-consuming laboratory determination would be reduced and it might be able to provide a potential tool in modeling food quality changes for the factory.

\section{Materials and Methods}

\section{Chemicals and Reagents}

Standard putrescine, cadaverine, spermine, spermidine, tryptamine, 2-phenylethylamine, histamine, tyramine and dansyl chloride (purity $>99 \%$ ) were purchased from Sigma-Aldrich. Acetonitrile (HighPerformance Liquid Chromatography (HPLC grade) and methanol (HPLC grade) were obtained from Tedia (USA). The other reagents were of analytical grade. Ultra-pure water $(18.2 \mathrm{M} \Omega \mathrm{cm})$ was produced using the Simplicity water purification system from Millipore (Bedford, MA, USA). The solutions of the BAs were prepared with $0.1 \mathrm{M} \mathrm{HCl}$.

\section{Sufu Samples}

On the basis of the dressing mixtures, sufu was classified into three types: White, red and grey sufu. A total of 108 bottles of sufu samples were purchased in local supermarkets. The samples of the three species were stored at $4^{\circ} \mathrm{C}, 15^{\circ} \mathrm{C}, 25^{\circ} \mathrm{C}$ and $35^{\circ} \mathrm{C}$, because consumers typically store sufu in a refrigerator $\left(4^{\circ} \mathrm{C}\right)$ or at room temperature. Moreover, $15^{\circ} \mathrm{C}, 25^{\circ} \mathrm{C}$ and $35^{\circ} \mathrm{C}$ represent the room temperatures in different seasons of the year. In view of the formation rates of BAs at different storage temperatures, the concentrations of BAs 
in the samples were determined for the following time intervals: 0,7 and 14 days at $4^{\circ} \mathrm{C}$ and $0,5,10$ and 15 days at $15^{\circ} \mathrm{C}, 25^{\circ} \mathrm{C}$ and $35^{\circ} \mathrm{C}$. The longest time of determination is 15 days, from then on, there will be obvious rotten smell of the preserved sufu after opening. Each sufu sample was analyzed in duplicate $(n=3)$.

\section{Preparation of Standard Solution}

BA stock solutions were individually prepared in 0.1 $\mathrm{M} \mathrm{HCl}$ at a given concentration of $1 \mathrm{mg} \mathrm{mL}^{-1}$. All BA solutions were refrigerated at $4^{\circ} \mathrm{C}$ and they remained stable at least for 20 days. In total, $10 \mathrm{mg} \mathrm{mL}^{-1}$ dansyl chloride solution was prepared in acetone.

\section{Determination of $B A$ Content}

The BAs were extracted and derivatized using the method developed by Saarinen (2002). Briefly, the BA contents were extracted by homogenizing a $2 \mathrm{~g}$ sample (each) with $20 \mathrm{~mL}$ of $0.1 \mathrm{M} \mathrm{HCl}$. Then, the extract was centrifuged for $30 \mathrm{~min}$ at $6000 \times \mathrm{g}$ and the supernatant was filtered. Next, $1 \mathrm{~mL}$ of the filtrate or standard was mixed with $0.3 \mathrm{~mL}$ of saturated sodium bicarbonate and $0.2 \mathrm{~mL}$ of $2 \mathrm{M} \mathrm{NaOH}$. The mixture was derivatized by $1 \mathrm{~mL}$ of dansyl chloride. Then, the mixture was vortexed for $1 \mathrm{~min}$ and incubated for $45 \mathrm{~min}$ at $42^{\circ} \mathrm{C}$. Afterward, the remaining dansyl chloride was consumed by the addition of $0.1 \mathrm{~mL}$ ammonia $(25 \%$ $\mathrm{v} / \mathrm{v}$ ). After $30 \mathrm{~min}$ of reaction (protected from light), the samples were filtered through a $0.45 \mu \mathrm{m}$ membrane prior to the HPLC analysis.

The BAs were determined by HPLC. The Waters HPLC system consisted of a Waters 1525 Binary HPLC pump, a Waters 2707 autosampler injector, a CTO-20AC oven, a DGU-20A5R degasser and a Waters 2489 ultraviolet-visible detector. Waters data processing was performed on a Waters Millennium data station. The chromatographic column $(5 \mu \mathrm{m}, 4.6 \times 250 \mathrm{~mm}$; Agilent Co., USA) had a column temperature of $40^{\circ} \mathrm{C}$. The binary mobile phase consisted of $0.1 \mathrm{~mol} \mathrm{~L}^{-1}$ ammonium acetate (A) and acetonitrile (B). The mobile phases were filtered through a $0.45 \mu \mathrm{m}$ membrane filter (Millipore, Bedford, MA, USA). The chromatograms were analyzed at $254 \mathrm{~nm}$ and the injection volume was $20 \mu \mathrm{L}$. The following gradient program was performed at a flow rate of $1 \mathrm{~mL} \mathrm{~min}^{-1}$ : $0.0-7.0 \mathrm{~min} 55.0-50.0 \% \mathrm{~B}, 7-25 \mathrm{~min}$ $50.0-90.0 \% \mathrm{~B}$ and $25.0-32 \min 90-55 \% \mathrm{~B}$.

\section{Determination of Physicochemical Properties}

The $\mathrm{pH}$ values of the samples were determined using a pH meter (Model 340, Mettler Toledo GmbH, Schwerzenbach, Switzerland). For each sample, a $5.0 \mathrm{~g}$ portion was collected, cut into pieces and homogenized with $40.0 \mathrm{~mL}$ of deionized water for $30 \mathrm{~min}$. The suspension was centrifuged at $6000 \times g$ for $10 \mathrm{~min}$. The supernatant was used to determine the $\mathrm{pH}$ value. The water activity $\left(\mathrm{a}_{\mathrm{w}}\right)$ was determined at $25^{\circ} \mathrm{C}$ by using a water activity meter (Novasina $\mathrm{AG}$, Switzerland).

Amino nitrogen was measured by formalin titration method (Xia et al., 2014) with slight modifications. Approximately $10 \mathrm{~mL}$ of the supernatant was mixed with $50 \mathrm{~mL}$ of water and titrated to $\mathrm{pH} 8.2$ with $0.05 \mathrm{M}$ $\mathrm{NaOH}$. Then, $10 \mathrm{~mL}$ of $36 \%(\mathrm{w} / \mathrm{v})$ formalin solution was added. The mixture was titrated to $\mathrm{pH} 9.2$ with $0.05 \mathrm{M}$ $\mathrm{NaOH}$. The volume of the consumed $\mathrm{NaOH}$ for increasing $\mathrm{pH}$ (from 8.2 to 9.2) was recorded to determine the amino nitrogen content.

\section{Grey Model}

Generally, the procedure of grey model is explained as follows:

Step1: The data of BAs in white sufu stored for $0,5,10$ and 15 days at $35^{\circ} \mathrm{C}$ were selected as the prediction data segment and the original data were accumulated to generate a cumulative data sequence:

$x^{(0)}=\left(x^{(0)}(1), x^{(0)}(2), \cdots, x^{(0)}(4)\right)$

Step2: Accumulation is a method of graying process, which plays an important role in the grey system. By accumulating and generating, the integral characteristics or laws contained in the chaotic original data can be fully revealed:

$x^{(1)}(1)=x^{(0)}(1)$

$x^{(1)}(k+1)=\left[x^{(1)}(k)+x^{(0)}(k+1)\right]$

$=\sum_{i=1}^{k+1} x^{(0)}(i), k=1,2, \cdots, n-1$

The background value is selected by taking the weighted average of accumulated data as the background value and $\alpha$ is the determining parameter:

$z^{(1)}(k+1)=\alpha x^{(1)}(k+1)+(1-\alpha) x^{(1)}(k),(k=1,2,3)$

Step3: Establishment of a model for the albino differential equation of GM:

$\frac{d x^{(1)}}{d t}+a x^{(1)}=u$

where, $a$ is the developed grayscale and $u$ is the endogenously controlled grayscale.

Step4: Establishing a first-order grey differential equation:

$x^{(0)}(k)+a z^{(1)}(k)=u,(k=2,3,4)$ 


$$
\begin{aligned}
& Y=B\left[\begin{array}{l}
a \\
u
\end{array}\right]=B A \\
& Y=\left(x^{(0)}(2), x^{(0)}(3)\right), B=\left[\begin{array}{cc}
-z^{(1)}(1) & 1 \\
-z^{(1)}(2) & 1 \\
\vdots & \vdots \\
-z^{(1)}(4) & 1
\end{array}\right], A=\left[\begin{array}{l}
a \\
u
\end{array}\right]
\end{aligned}
$$

Step5: Conversion to time response function, least squares method was used to obtain the estimators $(\hat{a}, \hat{u})$ for the parameters. Then, the solution of the grey differential equation was acquired:

$$
\widehat{A}=\left[\begin{array}{l}
\hat{a} \\
\widehat{u}
\end{array}\right]=\left(B^{T} B\right)^{-1} B^{T} Y
$$

The solution of the differential equation:

$$
\begin{aligned}
& \hat{x}^{(1)}(k+1)=\left(x^{(1)}(1)-\frac{u}{a}\right) e^{-a k}+\frac{u}{a} \\
& \hat{x}^{(0)}(k+1)=-a\left(x^{(0)}(1)-\frac{u}{a}\right) e^{-a k}
\end{aligned}
$$

Notice that the symbol` indicates a predicted value.

\section{Artificial Neural Network (ANN)}

Artificial Neural Network (ANN) is a nonlinear operational model used for classification and prediction. As its name implies, a typical ANN is composed of a large number of interconnected neurons to simulate the structure and function of the brain's nervous system, it can automatically induct rules from the known data, so we could get the inherent laws of these data and it has strong nonlinear mapping ability. These neurons are distributed on three layers: An input layer, an output layer and a hidden layer. The input layer links the network to the control variables, the hidden layer supplies the nonlinear functions for conversing input space to hidden space with high dimensionality and the output layer eventually provides the response of the input layer. The number of hidden layers and neurons in hidden layer could be regarded as design parameters. In this study, a one-hidden-layer network was performed as showed in Fig. 1. The input layer was composed of the following variables: Temperature and storage time and the output layer consisted of four neurons which indicated $\mathrm{pH}$ values, water activity, amino nitrogen and biogenic amines. An optimal choice of the number of hidden layers was performed, $5,6,7,8,9,10,11,12$ or 13 neurons were compared. The neural network distributed the database into three sets: (training, validation and test), account for $70 \%$, $15 \%$ and $15 \%$, separately.

\section{Evaluation of Grey Model and ANN}

To assess the accuracy of these two models in prediction, in the ANN, the Mean Square Error (MSE) was used to analyze the model precision and the regression coefficients $R^{2}$ was selected to ensure the minimum difference between the experimental value and the predicted value in training, validation and test data. In the Grey model, the regression coefficients $\mathrm{R}^{2}$ and the relative error between predicted and experimental value were proposed.

\section{Statistical Analysis}

Each experiment was conducted in three bottles and the analyses were performed in triplicate for each bottle. The results were presented as means \pm standard deviation. Analysis of variance was accomplished using Tukey's multiple range tests $(\mathrm{p}<0.05)$ to compare the means for different sampling days during the evolution of sufu. These statistical analyses were performed using the IBM SPSS Statistics Package version 22.0 (SPSS Inc., Chicago, IL, USA). The Grey Model (GM) was established to predict changes in BA levels. The model was created using MATLAB R2012a (MathWorks, Inc., Natick, Massachusetts, USA).

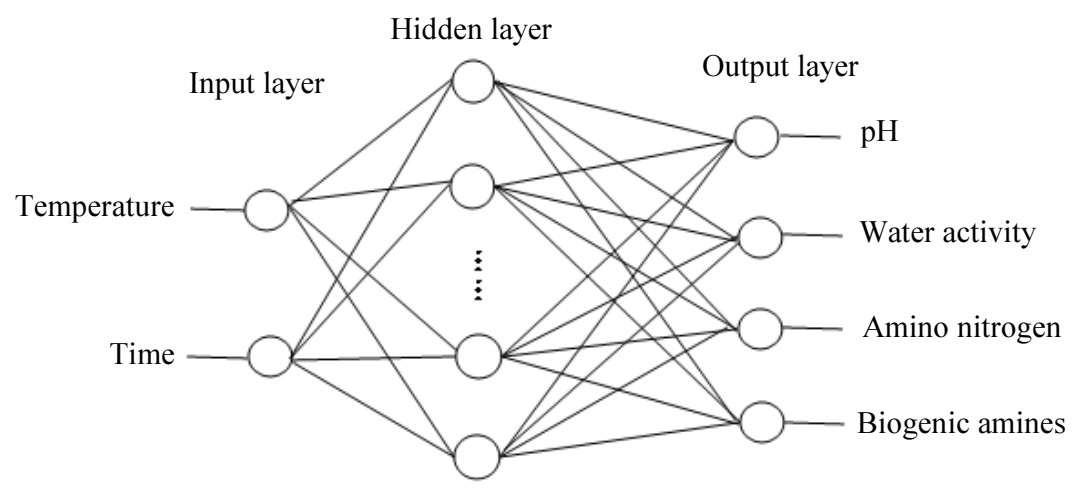

Fig. 1: Artificial neural networks for predicting quality changes of sufu during storage 


\section{Results and Discussion}

\section{BA Concentrations in Just Opened Sufu Samples}

The BA concentrations $\left(\mathrm{mg} \mathrm{kg}^{-1}\right)$ of different sufu samples are shown in Supplementary Material. The total contents of BAs varied markedly for different types of sufu, ranging from $311.52 \mathrm{mg} \mathrm{kg}^{-1}$ to 603.10 $\mathrm{mg} \mathrm{kg}{ }^{-1}$. The maximum content of BAs was found in grey sufu, which was twice of that in red sufu $(311.52$ $\mathrm{mg} \mathrm{kg}^{-1}$ ). These results might be due to the various flavors in the sufu. Red sufu contains red kojic rice and yellow wine, which exert inhibitory effects on the microorganisms. These results were consistent with the findings of García-Marino et al. (2010) who observed that grey sufu had higher levels of BAs than white and red sufu.

Among BAs, histamine is one of the most potentially harmful. Excessive histamine can cause hypotension, headaches, chemical poisoning and other human health problems (Kung et al., 2007). In the present study, the most abundant BAs in all samples were histamine and tyramine (Supplementary Table S1). The high levels of histamine and tyramine in tofu have also been reported by Han et al. (2004). The content of histamine varied markedly among the samples, ranging between $50.96 \mathrm{mg}$ $\mathrm{kg}^{-1}$ and $195.67 \mathrm{mg} \mathrm{kg}^{-1}$. This result slightly differed from the findings of Kung et al. (2007), who detected histamine in excess of $50 \mathrm{mg} \mathrm{kg}{ }^{-1}$ in only one red sample. This discrepancy might be attributed to the differences in the manufacturing processes and microorganism starter in the production process of sufu.

Putrescine and cadaverine were present in all sufu and the concentration of putrescine in red sufu $\left(20.07 \pm 1.45 \mathrm{mg} \mathrm{kg}^{-1}\right)$ was significantly lower $(\mathrm{p}<0.05)$ than that in white $\left(42.20 \pm 1.31 \mathrm{mg} \mathrm{kg}^{-1}\right)$ and grey sufu $\left(196.07 \pm 10.56 \mathrm{mg} \mathrm{kg}^{-1}\right)$. These findings agreed with those reported by Han et al. (2001). Han et al. (2001) detected putrescine and cadaverine in all sufu samples. Putrescine and cadaverine were the primary amines in all sufu products, which could be associated with poor hygienic conditions (Guan et al., 2013). In addition, the presence of cadaverine has been associated with the action of enterococci and coliform bacteria (Bover-Cid et al., 2003).

For the rest of the BAs, only two samples presented lower levels of spermine $\left(0.75-2.48 \quad \mathrm{mg} \mathrm{kg}{ }^{-1}\right)$. Spermidine, phenylethylamine and tryptamine had very low contents in most of the analyzed sufu.

\section{Changes of BAs and Physicochemical Properties During Storage}

The changes of eight BAs in sufu stored at $4^{\circ} \mathrm{C}$, $15^{\circ} \mathrm{C}, 25^{\circ} \mathrm{C}$ and $35^{\circ} \mathrm{C}$ are summarized (Supplementary Table S1-3).
In white sufu, the total amount of BAs did not exhibit a clear and significant trend during storage. The initial value of total BAs was $419.61 \mathrm{mg} \mathrm{kg}^{-1}$, which rapidly increased to $908.73,536.82$ and $466.12 \mathrm{mg} \mathrm{kg}^{-1}$ at the end of storage at $4{ }^{\circ} \mathrm{C}, 15^{\circ} \mathrm{C}$ and $35^{\circ} \mathrm{C}$. At $25^{\circ} \mathrm{C}$, the level of total BAs was slightly changed. The same trend was observed in histamine possibly because histamine is the dominant BA and its changes will affect the total BAs. This result also revealed that the production of BAs in white sufu was hardly related to temperature. This result contradicted the findings of other investigators (Bakar et al., 2010). Bakar et al. (2010) found that histamine gradually increased in barramundi slices during storage at different temperatures. The concentrations of phenylethylamine and spermidine fluctuated along time under all conditions, their amounts were so low that they did not affect the total concentrations. Unlike white sufu, the initial values of total BAs in red sufu was $311.52 \mathrm{mg} \mathrm{kg}^{-1}$, which rapidly increased to 398.72 and $338.41 \mathrm{mg} \mathrm{kg}^{-1}$ at the end of storage at $4{ }^{\circ} \mathrm{C}$ and $15^{\circ} \mathrm{C}$, respectively (Supplementary Table S1-2). The histamine concentrations significantly increased from the fifth day to the tenth day under all conditions, similar to that in white sufu.

For grey sufu, slight differences were observed under the different conditions of storage. The total amount of BAs significantly increased $(p<0.05)$ with higher storage temperatures. At $35^{\circ} \mathrm{C}$, the total amount of BAs in grey sufu reached $985 \mathrm{mg} \mathrm{kg}^{-1}$, which is twice that of white sufu (Supplementary Table S4).

In general, the BAs in the three types of sufu did not exhibit a common trend. Nonetheless, the histamine concentration significantly increased from the fifth day to the tenth day in the three types of sufu. This finding was consistent with Chin and Koehler (1986), who observed that the content of histamine increased during miso fermentation. Moreover, the different storage conditions employed in this experiment did not affect the BA profiles, except that the BAs were higher in grey sufu at $35^{\circ} \mathrm{C}$. Similarly, most BAs only slightly changed during their storage at different temperatures in closed red wine bottles (González Marco and Ancín Azpilicueta, 2006).

Supplementary Fig. S1 showed the water activity changes of sufu during storage. The $\mathrm{pH}$ value varied markedly among the three kinds of samples, 5.93-7.77 (Supplementary Fig. S2), which was similar to the value reported by Han et al. (2001). The $\mathrm{pH}$ value in white sufu increased over time $\left(15^{\circ} \mathrm{C}, 25^{\circ} \mathrm{C}\right.$ and $\left.35^{\circ} \mathrm{C}\right)$, whereas the grey and red sufu demonstrated an opposite trend. The difference was due to the variation of the lactic acid bacteria population in sufu (Li et al., 2014).

At $4^{\circ} \mathrm{C}$, the amino nitrogen in the white sufu increased significantly $(p<0.05)$ over time, which may be attributed to the restriction of the degradation degree of 
the water-soluble protein by alcohol. Alcohol is added in white sufu and it exerts an inhibitory effect on the activity of microorganism-induced protease, which would restrict the degradation of soybean proteins during the sufu ageing period (Chou and Hwan, 1994). However, during storage at $15^{\circ} \mathrm{C}, 25^{\circ} \mathrm{C}$ and $35^{\circ} \mathrm{C}$, the amino nitrogen increased slightly and then gradually decreased (Supplementary Fig. S3). Similar trends in amino nitrogen were observed by Andic et al. (2010).

\section{The Grey Model}

The dataset of $\mathrm{pH}$, water activity, amino nitrogen and total biogenic amines in white sufu during storage were collected to establish the grey model. The corresponding criterion of the relative error was listed in Table 1. It can be seen from Table 2 that the average relative error of $\mathrm{pH}$, water activity, amino nitrogen and total biogenic amines was $0.51 \%, 0.21 \%, 3.80 \%$ and $21.78 \%$, respectively. According to Table 1, a majority of the prediction errors are controlled below $10 \%$, which indicates a reasonable prediction in the model. The relative error of total biogenic amines exceed $10 \%$, the result may be caused by chaotic data and the normalization can prevent the overflow error caused by independent variables. In this experiment, we also consider the regression coefficients $\mathrm{R}^{2}$ between the experimental value and the predicted value, the results were presented in Fig. 2. As seen in these figures, there is good correlation between the predicted and experimental data. The predicted values are very close to the observed values, the statistical parameters $\left(\mathrm{R}^{2}\right)$ of $\mathrm{pH}$, water activity and amino nitrogen were all above 0.90 . According to previous works, the accuracy of the $\operatorname{GM}(1,1)$ model used for predicting the drying process based on four-point data was better than the other exponential models (Chen et al., 2010) and Chung et al. (2008) has shown that grey-based Taguchi method have effectively improved and solved optimization problems of a fermentation process with multiple performance characteristics.

Table 1: Criterion of the relative error in grey model

\begin{tabular}{ll}
\hline Forecasting power & Relative error \\
\hline Excellent Table 1 & $<1 \%$ \\
Good & $1 \%-5 \%$ \\
Reasonable & $5 \%-10 \%$ \\
Incorrect & $>10 \%$ \\
\hline
\end{tabular}

Table 2: Experimental values, grey model predicted values, and relative errors of $\mathrm{pH}$, water activity, amino nitrogen and biogenic amines of sufu during storage at different temperatures

\begin{tabular}{|c|c|c|c|c|c|c|c|c|c|c|c|c|c|}
\hline \multirow[b]{2}{*}{$\begin{array}{l}\text { Temperature } \\
\left(\mathrm{C}^{\circ}\right)\end{array}$} & \multirow[b]{2}{*}{$\begin{array}{l}\text { Storage } \\
\text { time (days) }\end{array}$} & \multicolumn{3}{|l|}{$\mathrm{pH}$} & \multicolumn{3}{|l|}{ Water activity } & \multicolumn{3}{|l|}{ Aminonitrogen } & \multicolumn{3}{|c|}{ Biogenic amines } \\
\hline & & $\begin{array}{l}\text { Experimental } \\
\text { value }\end{array}$ & $\begin{array}{l}1 \text { Predicted } \\
\text { value }\end{array}$ & $\begin{array}{l}\text { Relative } \\
\text { errors (\%) }\end{array}$ & $\begin{array}{l}\text { Experimental } \\
\text { value }\end{array}$ & $\begin{array}{l}\text { Predicted } \\
\text { value }\end{array}$ & $\begin{array}{l}\text { Relative } \\
\text { errors (\%) }\end{array}$ & $\begin{array}{l}\text { Experimental } \\
\text { value }\end{array}$ & $\begin{array}{l}\text { Predicted } \\
\text { value }\end{array}$ & $\begin{array}{l}\text { Relative } \\
\text { errors (\%) }\end{array}$ & $\begin{array}{l}\text { Experimental } \\
\text { value }\end{array}$ & $\begin{array}{l}\text { Predicted } \\
\text { value }\end{array}$ & $\begin{array}{l}\text { Relative } \\
\text { errors (\%) }\end{array}$ \\
\hline \multirow[t]{3}{*}{4} & 0 & 6.40 & 6.40 & 0.00 & 0.88 & 0.88 & 0.00 & 0.19 & 0.19 & 0.00 & 419.61 & 419.61 & 0.00 \\
\hline & 7 & 7.02 & 7.01 & 0.01 & 0.88 & 0.88 & 0.00 & 0.17 & 0.17 & 0.08 & 193.43 & 139.24 & 38.92 \\
\hline & 14 & 6.82 & 6.82 & 0.01 & 0.89 & 0.89 & 0.00 & 0.19 & 0.19 & 0.09 & 908.73 & 509.89 & 78.22 \\
\hline \multirow[t]{4}{*}{15} & 0 & 6.40 & 6.40 & 0.00 & 0.88 & 0.88 & 0.00 & 0.19 & 0.19 & 0.00 & 419.61 & 419.61 & 0.00 \\
\hline & 5 & 6.69 & 6.74 & 0.81 & 0.88 & 0.88 & 0.44 & 0.17 & 0.17 & 0.57 & 292.50 & 415.33 & 29.57 \\
\hline & 10 & 7.07 & 6.96 & 1.50 & 0.87 & 0.86 & 0.92 & 0.14 & 0.15 & 0.72 & 705.50 & 506.49 & 39.29 \\
\hline & 15 & 7.13 & 7.18 & 0.71 & 0.84 & 0.85 & 0.48 & 0.12 & 0.12 & 0.80 & 536.82 & 617.67 & 13.09 \\
\hline \multirow[t]{4}{*}{25} & 0 & 6.40 & 6.40 & 0.00 & 0.88 & 0.88 & 0.00 & 0.19 & 0.19 & 0.00 & 419.61 & 419.61 & 0.00 \\
\hline & 5 & 6.62 & 6.67 & 0.82 & 0.89 & 0.89 & 0.13 & 0.18 & 0.18 & 4.05 & 422.98 & 538.74 & 21.49 \\
\hline & 10 & 7.02 & 6.91 & 1.51 & 0.88 & 0.88 & 0.27 & 0.15 & 0.16 & 10.55 & 764.51 & 528.02 & 44.79 \\
\hline & 15 & 7.10 & 7.15 & 0.71 & 0.87 & 0.87 & 0.14 & 0.16 & 0.15 & 5.25 & 396.73 & 517.51 & 23.34 \\
\hline \multirow[t]{4}{*}{35} & 0 & 6.40 & 6.40 & 0.00 & 0.88 & 0.88 & 0.00 & 0.19 & 0.19 & 0.00 & 419.61 & 419.61 & 0.00 \\
\hline & 5 & 6.73 & 6.76 & 0.43 & 0.89 & 0.88 & 0.18 & 0.17 & 0.16 & 6.76 & 495.71 & 544.95 & 9.04 \\
\hline & 10 & 6.98 & 6.92 & 0.82 & 0.88 & 0.89 & 0.35 & 0.13 & 0.15 & 19.78 & 632.44 & 531.30 & 19.04 \\
\hline & 15 & 7.07 & 7.09 & 0.39 & 0.89 & 0.89 & 0.17 & 0.15 & 0.14 & 8.74 & 466.12 & 517.99 & 10.01 \\
\hline
\end{tabular}

Table 3: Changes of MSE and $\mathrm{R}^{2}$ between experimental and predicted values of training, validation and testing data in different hidden neurons in the ANN

\begin{tabular}{|c|c|c|c|c|c|c|}
\hline Neurons & $\begin{array}{l}\mathrm{R}^{2} \\
(\mathrm{TR})\end{array}$ & $\begin{array}{l}\mathrm{R}^{2} \\
(\mathrm{VA})\end{array}$ & $\begin{array}{l}\mathrm{R}^{2} \\
(\mathrm{TE})\end{array}$ & $\begin{array}{l}\text { MSE } \\
\text { (TR) }\end{array}$ & $\begin{array}{l}\text { MSE } \\
\text { (VA) }\end{array}$ & $\begin{array}{l}\text { MSE } \\
\text { (TE) }\end{array}$ \\
\hline 5 & 0.83 & 0.98 & 0.94 & 0.13 & 0.02 & 0.06 \\
\hline 6 & 0.99 & 0.86 & 0.94 & 0.01 & 0.13 & 0.17 \\
\hline 7 & 0.99 & 0.81 & 0.95 & 0.01 & 0.20 & 0.05 \\
\hline 8 & 0.94 & 0.87 & 0.71 & 0.06 & 0.31 & 0.45 \\
\hline 9 & 0.99 & 0.82 & 0.89 & 0.01 & 0.42 & 2.64 \\
\hline 10 & 0.99 & 0.99 & 0.98 & 0.01 & 0.01 & 0.02 \\
\hline 11 & 0.99 & 0.95 & 0.88 & 0.01 & 0.06 & 1.05 \\
\hline 12 & 0.98 & 0.80 & 0.89 & 0.02 & 0.54 & 0.08 \\
\hline 13 & 0.89 & 0.93 & 0.91 & 0.96 & 0.78 & 2.56 \\
\hline
\end{tabular}

"TR" indicates the training data. "VA" indicates that the 

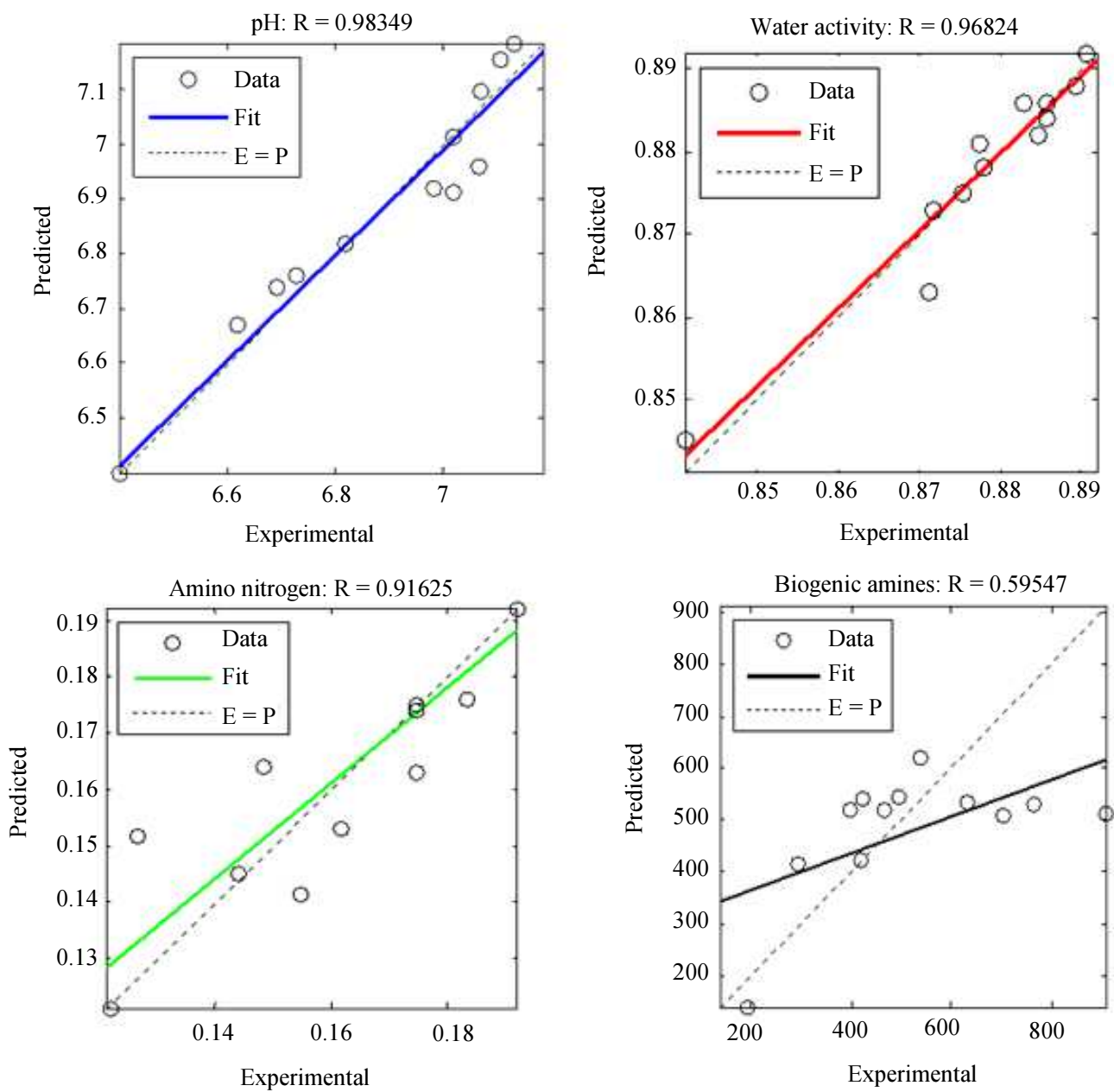

Fig. 2: Comparison between experimental and predicted values of $\mathrm{pH}$, water activity, amino nitrogen, and biogenic amines in grey model. "fit" indicates the best linear fit. "E $=\mathrm{P}$ " indicates that the experimental values is equal to the predicted values

\section{Model Development and Validation of Artificial Neural Network (ANN)}

In our model, the sample data is preprocessed in order to clean chaotic data before the execution of ANN. A min-max normalization method has to be employed to transform data measured on different scales to a notionally common scale. The normalization can prevent the overflow error caused by independent variables when calculating the parameters of our model.

In this study, experimental data of white sufu during storage at $4^{\circ} \mathrm{C}, 15^{\circ} \mathrm{C}, 25^{\circ} \mathrm{C}$ and $35^{\circ} \mathrm{C}$ was used for modeling with a distribution as follows: $70 \%$ for the training, $15 \%$ for the validation and $15 \%$ for the test.

The number of neurons in the hidden layer has been optimized so that the influence of temperature, time of conservation on quality changes could be accurately predicted. The optimal network was chosen following the values of the mean square error (MSE) and the coefficient $\left(R^{2}\right)$. The lowest MSE and the highest $R^{2}$ were expected for the optimal network. The results obtained in this optimization (Table 3). It can be seen from Table 3 that ten neurons in the hidden layer presented the lowest MSE (MSE $=0.01$ for training; MSE $=0.01$ for validation and MSE $=0.02$ for testing) and highest $R^{2}\left(R^{2}=0.99\right.$ for training; $R^{2}=0.99$ for validation and $R^{2}=0.98$ for testing), good agreement between experimental and predicted data was obtained. The ANN model accurately predicts the influence of agglomeration process parameters on physical and chemical properties of cocoa powder mixtures $\left(\mathrm{R}^{2}=\right.$ 0.949) (Benkovic et al., 2015). Furthermore, radial basis function neural networks (RBFNNs) were developed to predict quality of brined carp fillets during frozen storage with relative errors all within $\pm 5 \%$ (Kong et al., 2016). Therefore, in this study, ten hidden neurons was chosen to obtain a proposed model. A log-sigmoidal activation function and a linear activation function were performed in the hidden layer and output layer, respectively. 

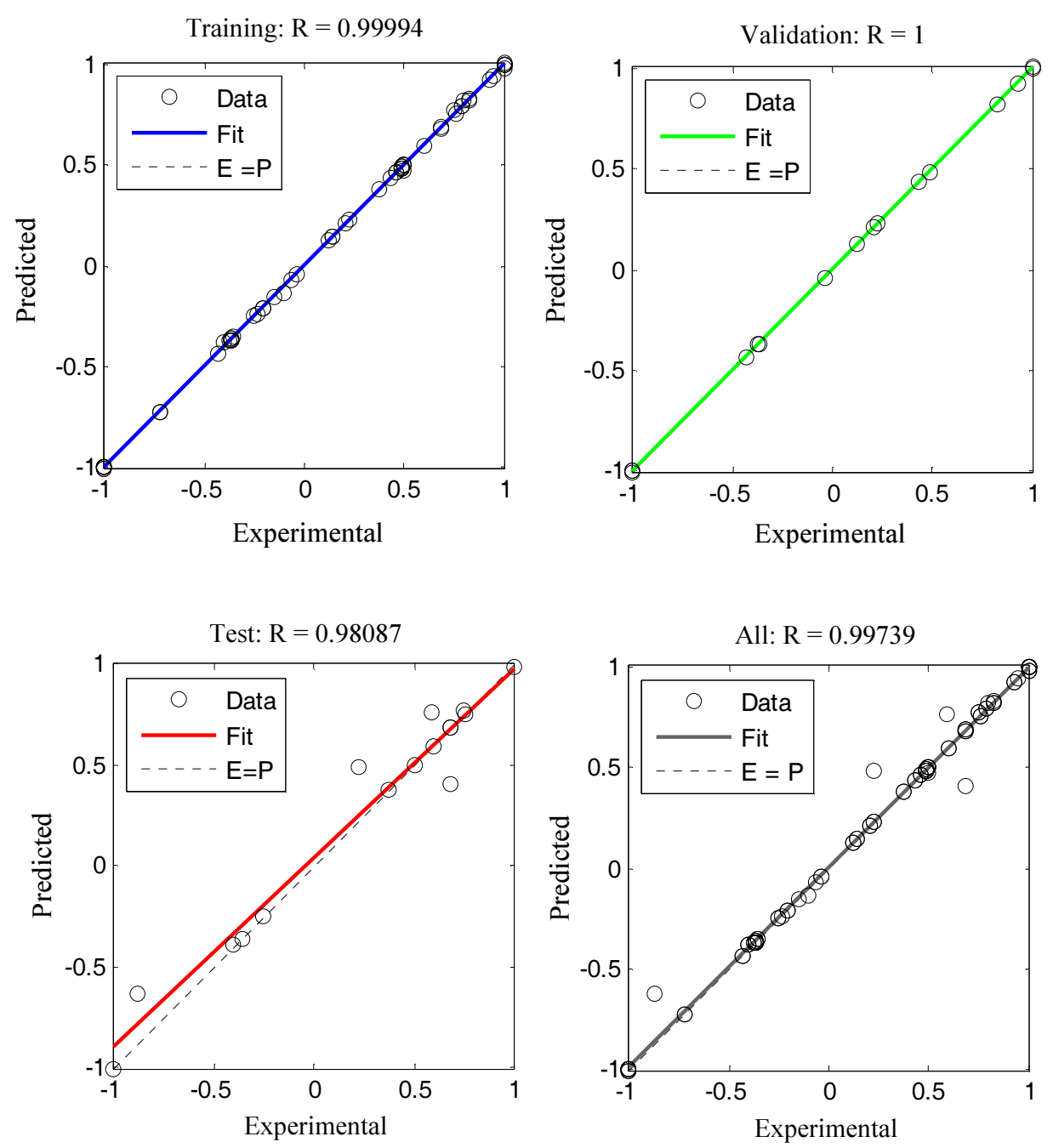

Fig. 3: Comparison between experimental and predicted values of training, validation and testing data in ANN. "fit" indicates the best linear fit. " $\mathrm{E}=\mathrm{P}$ " indicates that the experimental values is equal to the predicted values

Based on the ANN with ten hidden neurons, highest $\mathrm{R}^{2}$ (Fig. 3) $\left(\mathrm{R}^{2}=0.99\right.$ for training; $\mathrm{R}^{2}=1.0$ for validation; $R^{2}=0.98$ for testing and $R^{2}=0.99$ for all) was found to estimate quality changes in sufu.

We predict the changes of biogenic amines in sufu over the next 40 days and based on our prediction results, if uncapped grey sufu was stored in the refrigerator $\left(4^{\circ} \mathrm{C}\right)$, it is recommended that it should be eaten within 25 days, otherwise the content of biogenic amines will exceed $1000 \mathrm{mg} \mathrm{kg}^{-1}$, for other storage temperatures, grey sufu should be consumed in a shorter period of time ( $<25$ days) (Supplementary Table S5).

\section{Conclusion}

During storage, the denaturation of proteins led to the decrease in amino nitrogen, this process also leads to the accumulation of free amino acids, some of which are the precursors of biogenic amines, which is related to water activity and $\mathrm{pH}$ value. For monitoring quality changes, artificial neural network with two different inputs (temperatures and time) was designed. A good correlation was observed between the values predicted and those obtained experimentally. Furthermore, in grey model the predicted values are very close to the observed values, the statistical parameters $\left(\mathrm{R}^{2}\right)$ of $\mathrm{pH}$, water activity and amino nitrogen were all above 0.90 . These results offer new prediction tool, particularly in the field of food storage, since they could be a potential tool in modeling food quality changes during storage.

\section{Funding Information}

This work was financially supported by the National Natural Science Foundation, China (Grant No. 
31601462); the Fundamental Research Funds for the Beijing Food Nutrition and Human Health Innovation Center, Open Foundation, China, Beijing (Grant No. 20161009); and the Science and Technology Research Project of Hebei Province (Grant No. BJ2017016).

\section{Author's Contributions}

Jingjing Liang: Has contributed in a whole experiment, data analysis, paper writing and publication.

Dawei Li and Ruiqin Shi: Have assisted in the experiment.

Yanli Ma, Jie Wang and Ke Xiong: Has reviewed and revised the manuscript.

\section{Ethics}

All authors read and approved the final version of this manuscript. There are not any ethical issues to declare that could arise after the publication of this manuscript.

\section{References}

Andic, S., H. Genccelep and S. Kose, 2010. Determination of biogenic amines in herby cheese. Int. J. Food Properties, 13: 1300-1314. DOI: $10.1080 / 10942910903061869$

Bakar, J., A. Yassoralipour, F.A. Bakar and R.A. Rahman, 2010. Biogenic amine changes in barramundi (Lates calcarifer) slices stored at $0^{\circ} \mathrm{C}$ and $4{ }^{\circ} \mathrm{C}$. Food Chem., 119: 467-470.

DOI: 10.1016/j.foodchem.2009.06.041

Benkovic, M., A.J. Tusek, A. Belscak-Cvitanovic, A. Lenart and E. Domian, 2015. Artificial neural network modelling of changes in physical and chemical properties of cocoa powder mixtures during agglomeration. LWT - Food Sci. Technol., 64: 140-148. DOI: 10.1016/j.lwt.2015.05.028

Bover-Cid, S., T. Hernandez-Jover, M.J. MiguelezArrizado and M.C. Vidal-Carou, 2003. Contribution of contaminant enterobacteria and lactic acid bacteria to biogenic amine accumulation in spontaneous fermentation of pork sausages. Eur. Food Res. Technol., 216: 477-482. DOI: $10.1007 / \mathrm{s} 00217-003-0691-6$

Chao, S.H., Y. Tomii, K. Watanabe and Y.C. Tsai, 2008. Diversity of lactic acid bacteria in fermented brines used to make stinky tofu. Int. J. Food Microbiol., 123: 134-141. I: 10.1016/j.ijfoodmicro.2007.12.010

Chen, H., P. Tsai, S. Chen, Y. Su and C. Chung et al., 2005. Grey relational analysis of dried roselle (Hibiscus sabdariffa L.). J. Food Process. Preservat., 29: 228-245.

DOI: $10.1111 / \mathrm{j} .1745-4549.2005 .00025 . \mathrm{x}$
Chen, H.H., C.C. Chung, C.H. Hsu and T.C. Huang, 2010. Application of grey prediction in a solar energy-assisted photocatalytic low-pressure drying process, drying technology. Int. J., 28: 1097-1106. DOI: $10.1080 / 07373937.2010 .506168$

Chin, K.D.H. and P.E. Koehler, 1986. Effect of salt concentration and incubation temperature on formation of histamine, phenethylamine, tryptamine and tyramine during miso fermentation. J. Food Protect., 49: 423-427.

DOI: 10.1016/0278-6915(86)90199-7

Chou, C.C. and C.H. Hwan, 1994. Effect of ethanol on the hydrolysis of protein and lipid during the ageing of a Chinese fermented soya bean curd-Sufu. J. Sci. Food Agric., 66: 393-398. DOI: $10.1002 /$ jsfa. 2740660318

Chung, C.C., H.H. Chen and P.C. Hsieh, 2008. Optimization of the Monascus purpureus fermentation process based on multiple performance characteristics. Int. J. Grey Syst., 11: 85-96.

Chung, C.C., H.H. Chen and C.H. Ting, 2010. Grey prediction fuzzy control for ph processes in the food industry. J. Food Eng., 96: 575-582.

DOI: $10.1016 /$ j.jfoodeng.2009.09.004

Elsanhoty, R.M. and M.F. Ramadan, 2016. Genetic screening of biogenic amines production capacity from some lactic acid bacteria strains. Food Control, 68: 220-228. DOI: 10.1016/j.foodcont.2016.04.002

Fang, T., L. Huang, L. Liu, F. Mei and J. Chen, 2015. Mathematical modeling of growth of Salmonella spp. and spoilage microorganisms in raw oysters. Food Control, 53: 140-146. DOI: 10.1016/j.foodcont.2014.12.036

García-Marino, M., Á. Trigueros and T. EscribanoBailón, 2010. Influence of oenological practices on the formation of biogenic amines in quality red wines. J. Food Compos. Anal., 23: 455-462. DOI: $10.1016 /$ j.jfca.2010.02.003

González Marco, A. and C. Ancín Azpilicueta, 2006. Amine concentrations in wine stored in bottles at different temperatures. Food Chem., 99: 680-685. DOI: 10.1016/j.foodchem.2005.08.043

Guan, R.F., Z.F. Liu, J.J. Zhang, Y.X. Wei and S. Wahab et al., 2013. Investigation of biogenic amines in sufu (furu): A Chinese traditional fermented soybean food product. Food Control, 31: 345-352. DOI: 10.1016/j.foodcont.2012.10.033

Han, B.Z., R.R. Beumer, F.M. Rombouts and M.J.R. Nout, 2001. Microbiological safety and quality of commercial sufu-a Chinese fermented soybean food. Food Control, 12: 541-547. DOI: $10.1016 / \mathrm{S} 0956-7135(01) 00064-0$ 
Han, B.Z., C.F. Cao, F.M. Rombouts and M.J.R. Nout, 2004. Microbial changes during the production of sufu-a Chinese fermented soybean food. Food Control, 15: 265-270.

DOI: $10.1016 / \mathrm{S} 0956-7135(03) 00066-5$

Komprda, T., R. Burdychova, V. Dohnal and O. Cwikova, 2008. Tyramine production in Dutch-type semi-hard cheese from two different producers. Food Microbiol., 25: 219-227. DOI: $10.1016 / \mathrm{j} . \mathrm{fm} .2007 .11 .006$

Kong, C.L., H.Y. Wang, D.P. Li, Y.M. Zhang and J.F. Pan et al., 2016. Quality changes and predictive models of radial basis function neural networks for brined common carp (Cyprinus carpio) fillets during frozen storage. Food Chem., 201: 327-333. DOI: 10.1016/j.foodchem.2016.01.088

Kung, H.F., Y.H. Lee, S.C. Chang, C.I. Wei and Y.H. Tsai et al., 2007. Histamine contents and histamineforming bacteria in sufu products in Taiwan. Food Control, 18: 381-386.

DOI: 10.1016/j.foodcont.2006.02.012

Li, Y.F., R.X. Xu, L.W. Jiang and M.M. Li, 2014. Study on microbial quantity and flavor components in stinky tofu brine. J. Food Safety Quality, 5: 3098-3109.

Liang, H., L. Deng and H. Lin, 2013. Distribution, functions and applications of lactic acid bacteria in traditional fermented soybean foods. Food Sci., 34: 381-385.

Liu, X., Y. Jiang, S. Shen and Y. Luo, 2015. Comparison of Arrhenius model and artificial neural network for the quality prediction of rainbow trout (Oncorhynchus mykiss) fillets during storage at different temperatures. LWT-Food Sci. Technol., 60: 142-147. DOI: 10.1080/10942912.2016.1248292
Llave, Y.A., T. Hagiwara and T. Sakiyama, 2012. Artificial neural network model for prediction of cold spot temperature in retort sterilization of starchbased foods. J. Food Eng., 109: 553-560.

DOI: 10.1016/j.jfoodeng.2011.10.024

Lou, W. and S. Nakai, 2000. Application of artificial neural networks for predicting the thermal inactivation of bacteria: A combined effect of temperature, $\mathrm{pH}$ and water activity. Food Res. Int., 34: 573-579. DOI: 10.1016/s0963-9969(01)00074-6

Saarinen, M.T., 2002. Determination of biogenic amines as dansyl derivatives in intestinal digesta and feces by reversed phase HPLC. Chromatographia, 55: 297-300. DOI: 10.1007/BF02491662

Schirone, M., R. Tofalo, G. Fasoli, G. Perpetuini and A. Corsetti et al., 2013. High content of biogenic amines in Pecorino cheeses. Food Microbiol., 34: 137-144. DOI: 10.1016/j.fm.2012.11.022

Sun, G.P., X.J. Zhang, Y. Wang, D. Wang and J.L. Xie, 2010. The investigation of bacteria diversity in stinky tofu brine. Modern Food Sci. Technol., 26: 1087-1091.

Tripathi, A.K. and A.K. Misra, 2005. Soybean - a consummate functional food: A review. J. Food Sci. Technol. Mysore, 42: 111-119.

USFDA, 2001. Fish and fishery products hazards and controls guide. Department of Health and Human Services, Public Health Service, Food and Drug Administration, Center for Food Safety and Applied Nutrition, Office of Seafood, Washington, DC.

Xia, X., G. Li, J. Zheng, C. Ran and J. Kan, 2014. Biochemical, textural and microstructural changes in whole-soya bean cotyledon sufu during fermentation. Int. J. Food Sci. Technol., 49: 1834-1841.

DOI: $10.1111 /$ ijfs. 12492

\section{Annex}

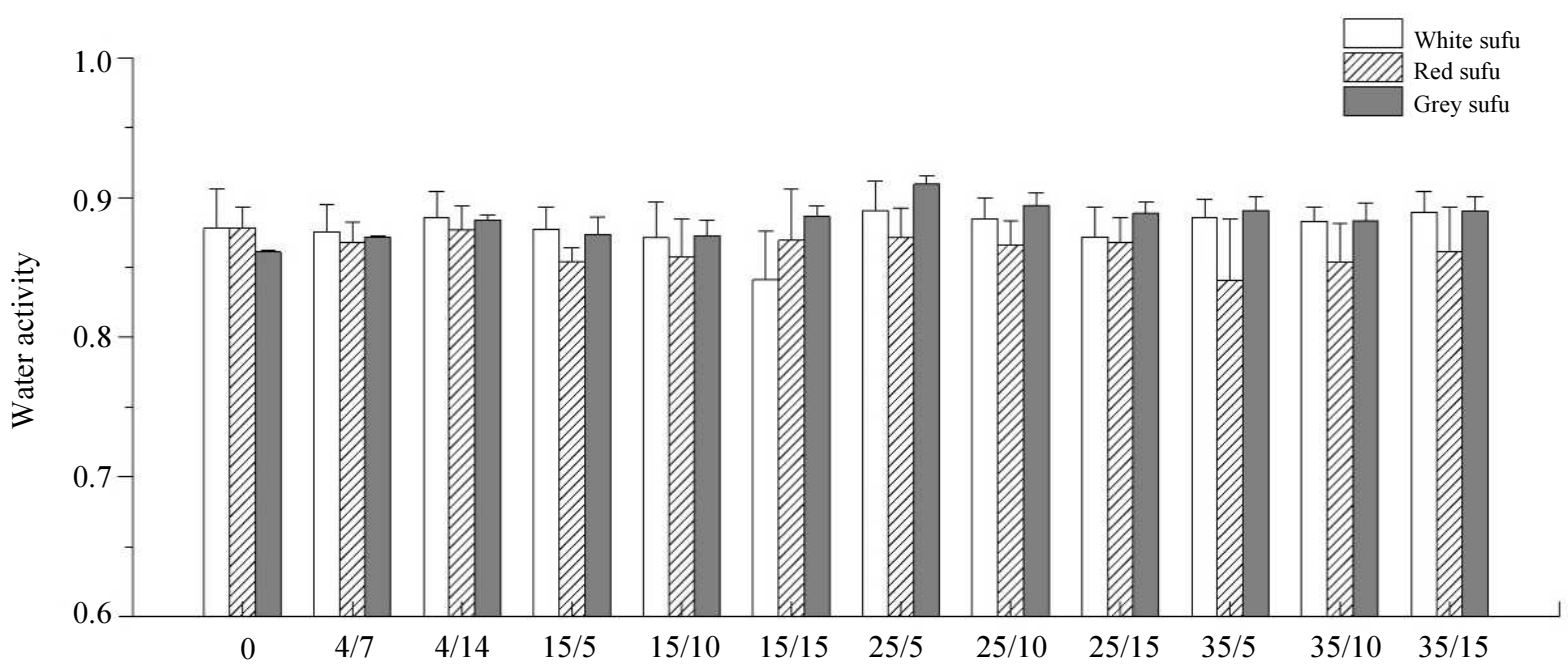

Supplementary Fig. S1: Effect of storage condition on the water activity of different sufu. Error bars represent the standard deviations of mean values. $a / b$ : a indicates the temperature; $b$ indicates the storage time(days) 


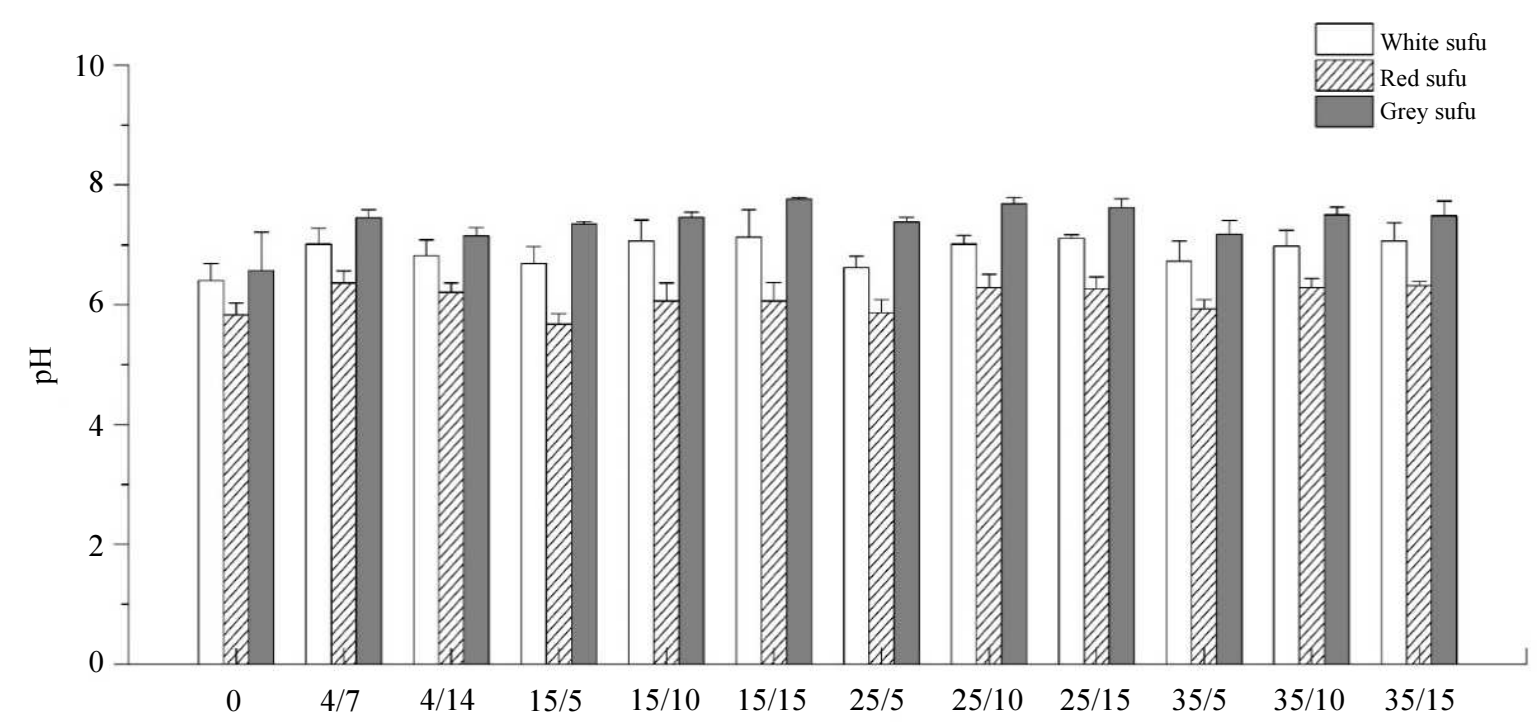

Supplementary Fig. S2: Effect of storage condition on the pH value of different sufu. Error bars represent the standard deviations of mean values. $a / b$ : $a$ indicates the temperature; $b$ indicates the storage time(days)

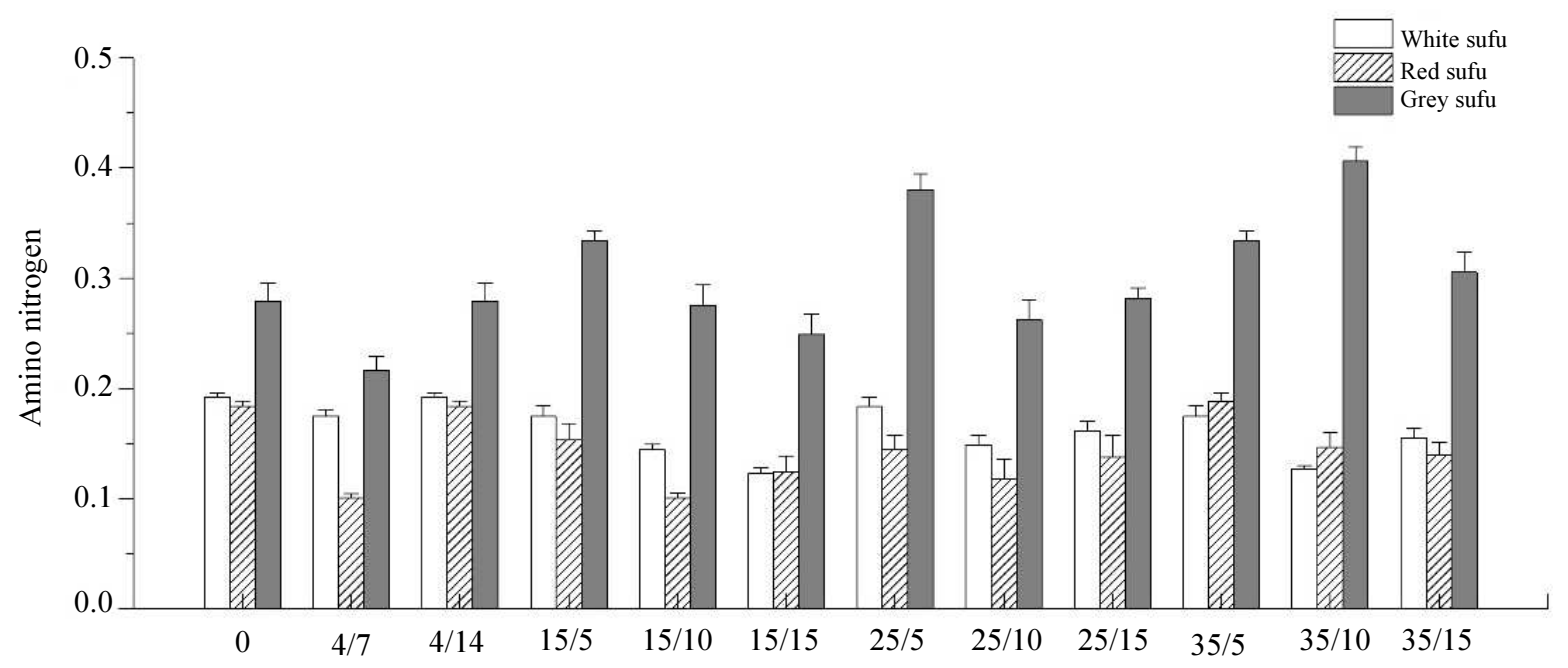

Supplementary Fig. S3: Effect of storage condition on the amino nitrogen of different sufu. Error bars represent the standard deviations of mean values. $\mathrm{a} / \mathrm{b}$ : $a$ indicates the temperature; $b$ indicates the storage time(days)

Supplementary Table S1: Evolution of biogenic amine concentrations in the three types of sufu at $4^{\circ} \mathrm{C}$

\begin{tabular}{|c|c|c|c|c|c|c|c|c|c|}
\hline \multirow{2}{*}{$\begin{array}{l}\text { Storage } \\
\text { time (days) }\end{array}$} & \multicolumn{9}{|c|}{ Biogenic amines $\left(\mathrm{mg} \mathrm{kg}^{-1}\right)$} \\
\hline & PUT & CAD & HIS & TYR & PHE & TRY & SPD & SPM & TOTALS \\
\hline \multicolumn{10}{|l|}{ White sufu } \\
\hline 0 & $42.20 \pm 1.31 \mathrm{c}$ & $38.43 \pm 1.99 \mathrm{a}$ & $158.17 \pm 8.99 \mathrm{~b}$ & $146.41 \pm 12.45 \mathrm{a}$ & $8.95 \pm 0.77 b$ & $10.42 \pm 0.45 \mathrm{c}$ & $14.91 \pm 0.85 \mathrm{ab}$ & ND & 419.61 \\
\hline 7 & $66.31 \pm 5.78 b$ & $31.81 \pm 2.36 \mathrm{~b}$ & $68.59 \pm 4.14 \mathrm{c}$ & $57.93 \pm 3.45 b$ & $5.29 \pm 0.77 \mathrm{c}$ & $66.51 \pm 3.87 \mathrm{a}$ & $15.07 \pm 1.69 \mathrm{a}$ & ND & 193.43 \\
\hline 14 & $127.81 \pm 7.89 \mathrm{Aa}$ & $24.39 \pm 0.90 \mathrm{Bc}$ & $336.59 \pm 18.26 \mathrm{Aa}$ & $57.49 \pm 2.73 \mathrm{Bb}$ & $20.48 \pm 1.99 \mathrm{a}$ & $24.7 \pm 1.12 \mathrm{Ab}$ & $11.60 \pm 0.91 \mathrm{Bc}$ & ND & 908.73 \\
\hline \multicolumn{10}{|l|}{ Red sufu } \\
\hline 0 & $20.07 \pm 1.45 \mathrm{a}$ & $24.11 \pm 2.41 \mathrm{a}$ & $50.96 \pm 2.56 \mathrm{~b}$ & $34.46 \pm 1.76 \mathrm{a}$ & $6.86 \pm 0.35 \mathrm{a}$ & $49.83 \pm 2.49 \mathrm{a}$ & $7.16 \pm 0.46 \mathrm{c}$ & ND & 311.52 \\
\hline 7 & $7.86 \pm 0.49 \mathrm{c}$ & $15.43 \pm 0.83 \mathrm{~b}$ & $57.09 \pm 2.46 \mathrm{~b}$ & $2.61 \pm 0.29 \mathrm{c}$ & $4.02 \pm 0.25 \mathrm{~b}$ & $27.27 \pm 1.61 \mathrm{~b}$ & $8.59 \pm 0.69 b$ & ND & 122.89 \\
\hline 14 & $11.37 \pm 1.12 \mathrm{Cb}$ & $17.62 \pm 0.88 \mathrm{Cb}$ & $339.63 \pm 19.52 \mathrm{Aa}$ & $33.36 \pm 1.01 \mathrm{Cab}$ & $4.12 \pm 0.26 \mathrm{~b}$ & $7.8 \pm 0.42 \mathrm{Bc}$ & $13.48 \pm 0.17 \mathrm{ABa}$ & ND & 398.72 \\
\hline \multicolumn{10}{|l|}{ Grey sufu } \\
\hline 0 & $196.07 \pm 10.56 \mathrm{a}$ & $30.60 \pm 2.66 \mathrm{ab}$ & $195.67 \pm 8.62 \mathrm{c}$ & $298.33 \pm 19.70 a$ & $49.51 \pm 2.50 \mathrm{a}$ & $125.37 \pm 6.10 \mathrm{a}$ & $13.21 \pm 0.72 \mathrm{ab}$ & ND & 603.1 \\
\hline 7 & $24.54 \pm 1.23 \mathrm{c}$ & $21.41 \pm 1.93 \mathrm{c}$ & $226.23 \pm 14.09 b$ & $76.28 \pm 3.53 \mathrm{c}$ & $19.00 \pm 1.26 \mathrm{~b}$ & $16.95 \pm 0.86 \mathrm{~b}$ & $14.18 \pm 1.69 \mathrm{ab}$ & ND & 427.42 \\
\hline 14 & $85.14 \pm 5.47 \mathrm{Bb}$ & $31.28 \pm 0.79 \mathrm{Aa}$ & $330.97 \pm 23.09 \mathrm{Aa}$ & $105.71 \pm 5.16 \mathrm{Ab}$ & $16.29 \pm 0.94 b$ & $4.74 \pm 0.20 \mathrm{Cc}$ & $15.72 \pm 0.98 \mathrm{Aa}$ & ND & 589.89 \\
\hline
\end{tabular}

Biogenic amines content is expressed in $\mathrm{mg} \mathrm{kg}^{-1}$ (mean $\pm \mathrm{SD}$ ).

"a-d" Different superscripts in the same column indicate significant statistical differences $(\mathrm{p}<0.05)$ in the same type of sample according to the Tukey's multiple range tests.

"A-C" Different superscripts in the same column indicate significant statistical differences $(\mathrm{p}<0.05)$ in the different type of sample stored for 15 days according to the Tukey's multiple range tests. 
JingJing Liang et al. / American Journal of Biochemistry and Biotechnology 2018, 14 (4): 285.297 DOI: 10.3844/ajbbsp.2018.285.297

\begin{tabular}{|c|c|c|c|c|c|c|c|c|c|}
\hline \multirow{2}{*}{$\begin{array}{l}\text { Storage } \\
\text { time (days) }\end{array}$} & \multicolumn{9}{|c|}{ Biogenic amines $\left(\mathrm{mg} \mathrm{kg}^{-1}\right)$} \\
\hline & PUT & $\mathrm{CAD}$ & HIS & TYR & PHE & TRY & SPD & SPM & TOTALS \\
\hline \multicolumn{10}{|l|}{ White sufu } \\
\hline 0 & $42.20 \pm 1.31 \mathrm{c}$ & $38.43 \pm 2.96 \mathrm{a}$ & $158.17 \pm 8.00 \mathrm{c}$ & $146.41 \pm 8.02 \mathrm{a}$ & $8.95 \pm 0.57 b$ & $10.42 \pm 0.45 \mathrm{~d}$ & $14.91 \pm 0.85 \mathrm{a}$ & ND & 419.61 \\
\hline 5 & $19.59 \pm 0.92 \mathrm{~d}$ & $30.88 \pm 1.01 \mathrm{c}$ & $70.39 \pm 3.90 \mathrm{~d}$ & $87.57 \pm 5.15 \mathrm{~d}$ & $6.88 \pm 0.35 \mathrm{c}$ & $66.64 \pm 3.72 \mathrm{a}$ & $10.52 \pm 0.82 \mathrm{c}$ & ND & 292.50 \\
\hline 10 & $165.92 \pm 9.21 \mathrm{a}$ & $34.11 \pm 1.35 b$ & $294.32 \pm 15.78 \mathrm{a}$ & $141.16 \pm 10.45 b$ & $4.56 \pm 0.21 \mathrm{~d}$ & $53.93 \pm 4.62 b$ & $11.48 \pm 0.75 \mathrm{c}$ & ND & 705.50 \\
\hline 15 & $128.10 \pm 6.17 \mathrm{Ab}$ & $31.51 \pm 0.84 \mathrm{Abc}$ & $184.78 \pm 10.59 \mathrm{Bb}$ & $119.36 \pm 5.70 \mathrm{Cc}$ & $11.22 \pm 0.63 \mathrm{Ba}$ & $47.12 \pm 2.27 \mathrm{Bc}$ & $13.99 \pm 0.81 \mathrm{Aab}$ & $0.75 \pm 0.11$ & 536.82 \\
\hline \multicolumn{10}{|l|}{ Red sufu } \\
\hline 0 & $20.07 \pm 2.45 \mathrm{c}$ & $24.11 \pm 2.41 \mathrm{~b}$ & $50.96 \pm 2.82 \mathrm{~d}$ & $34.46 \pm 1.76 c$ & $6.86 \pm 0.45 b$ & $49.83 \pm 2.41 \mathrm{~b}$ & $7.16 \pm 0.46 \mathrm{~d}$ & ND & 311.52 \\
\hline 5 & $29.67 \pm 2.08 \mathrm{a}$ & $7.51 \pm 0.36 \mathrm{~d}$ & $150.65 \pm 9.68 b$ & $34.48 \pm 1.45 \mathrm{c}$ & $2.47 \pm 0.13 \mathrm{c}$ & $70.52 \pm 4.48 \mathrm{a}$ & $11.60 \pm 1.15 \mathrm{bc}$ & ND & 306.90 \\
\hline 10 & $8.33 \pm 0.31 \mathrm{~d}$ & $27.67 \pm 1.45 \mathrm{a}$ & $169.04 \pm 8.57 \mathrm{a}$ & $184.89 \pm 9.14 \mathrm{a}$ & $2.77 \pm 0.23 \mathrm{c}$ & $12.55 \pm 1.15 \mathrm{~d}$ & $14.08 \pm 0.70 \mathrm{a}$ & ND & 419.33 \\
\hline 15 & $23.43 \pm 1.86 \mathrm{Cb}$ & $19.88 \pm 0.96 \mathrm{Ac}$ & $102.57 \pm 5.48 \mathrm{Cc}$ & $145.44 \pm 9.46 \mathrm{Bb}$ & $10.44 \pm 0.58 \mathrm{Ba}$ & $24.39 \pm 1.73 \mathrm{Cc}$ & $12.26 \pm 0.90 \mathrm{ABb}$ & ND & 338.41 \\
\hline \multicolumn{10}{|l|}{ Grey sufu } \\
\hline 0 & $196.07 \pm 10.56 \mathrm{a}$ & $30.60 \pm 2.66 \mathrm{~b}$ & $195.67 \pm 9.62 \mathrm{c}$ & $298.33 \pm 16.97 b$ & $49.51 \pm 2.50 \mathrm{a}$ & $125.37 \pm 6.10 \mathrm{a}$ & $13.21 \pm 0.72 b$ & ND & 603.10 \\
\hline 5 & $19.60 \pm 0.92 \mathrm{~d}$ & $6.61 \pm 0.27 \mathrm{~d}$ & $127.40 \pm 7.40 \mathrm{~d}$ & $123.16 \pm 10.68 \mathrm{~d}$ & $12.49 \pm 1.23 \mathrm{c}$ & $49.42 \pm 2.60 \mathrm{~d}$ & $19.05 \pm 1.51 \mathrm{a}$ & ND & 357.72 \\
\hline 10 & $28.73 \pm 1.72 \mathrm{c}$ & $39.40 \pm 1.93 \mathrm{a}$ & $454.66 \pm 48.44 \mathrm{a}$ & $306.31 \pm 15.53 \mathrm{a}$ & $8.15 \pm 0.42 \mathrm{~d}$ & $114.88 \pm 5.83 \mathrm{~b}$ & $10.82 \pm 0.46 \mathrm{bc}$ & ND & 962.94 \\
\hline 15 & $84.02 \pm 6.20 \mathrm{Bb}$ & $23.92 \pm 1.48 \mathrm{Ac}$ & $366.71 \pm 30.76 \mathrm{Ab}$ & $193.27 \pm 13.34 \mathrm{Ac}$ & $27.69 \pm 2.67 \mathrm{Ab}$ & $67.52 \pm 4.93 \mathrm{Ac}$ & $11.98 \pm 2.02 \mathrm{Bbc}$ & ND & 775.09 \\
\hline
\end{tabular}

Biogenic amines content is expressed in $\mathrm{mg} \mathrm{kg}^{-1}$ (mean $\pm \mathrm{SD}$ ).

"a-d" Different superscripts in the same column indicate significant statistical differences $(p<0.05)$ in the same type of sample according to the Tukey's multiple range tests.

"A-C" Different superscripts in the same column indicate significant statistical differences $(p<0.05)$ in the different type of sample stored for 15 days according to the Tukey's multiple range tests

Supplementary Table S3: Evolution of biogenic amine concentrations in the three types of sufu at $25^{\circ} \mathrm{C}$

\begin{tabular}{|c|c|c|c|c|c|c|c|c|c|}
\hline \multirow{2}{*}{$\begin{array}{l}\text { Storage } \\
\text { time (days) }\end{array}$} & \multicolumn{9}{|c|}{ Biogenic amines $\left(\mathrm{mg} \mathrm{kg}^{-1}\right)$} \\
\hline & PUT & $\mathrm{CAD}$ & HIS & TYR & PHE & TRY & SPD & SPM & TOTALS \\
\hline \multicolumn{10}{|l|}{ White sufu } \\
\hline 0 & $42.20 \pm 1.31 \mathrm{~d}$ & $38.43 \pm 1.96 \mathrm{ab}$ & $158.17 \pm 10.00 c$ & $146.41 \pm 9.02 \mathrm{a}$ & $8.95 \pm 0.78 \mathrm{ac}$ & $10.42 \pm 0.45 \mathrm{~d}$ & $14.91 \pm 0.85 \mathrm{a}$ & ND & 419.61 \\
\hline 5 & $108.71 \pm 6.54 \mathrm{c}$ & $17.50 \pm 1.18 \mathrm{~d}$ & $170.86 \pm 9.69 b$ & $80.77 \pm 5.61 \mathrm{~d}$ & $9.49 \pm 0.61 \mathrm{a}$ & $23.69 \pm 1.94 \mathrm{c}$ & $11.97 \pm 0.78 \mathrm{bc}$ & ND & 422.98 \\
\hline 10 & $189.11 \pm 10.34 \mathrm{a}$ & $29.58 \pm 1.56 \mathrm{c}$ & $357.94 \pm 18.49 a$ & $120.36 \pm 10.49 b$ & $9.18 \pm 0.35 \mathrm{ab}$ & $46.68 \pm 2.78 b$ & $11.67 \pm 1.16 \mathrm{bc}$ & ND & 764.51 \\
\hline 15 & $132.32 \pm 7.86 \mathrm{Ab}$ & $40.16 \pm 1.19 \mathrm{Aa}$ & $56.57 \pm 3.58 \mathrm{Bd}$ & $97.98 \pm 8.02 \mathrm{Bc}$ & $6.47 \pm 0.49 \mathrm{Bd}$ & $50.95 \pm 3.16 \mathrm{Aa}$ & $12.29 \pm 1.05 \mathrm{Ab}$ & ND & 396.73 \\
\hline \multicolumn{10}{|l|}{ Red sufu } \\
\hline 0 & $20.07 \pm 1.45 b$ & $24.11 \pm 2.41 \mathrm{a}$ & $50.96 \pm 3.82 b$ & $34.46 \pm 1.76 \mathrm{a}$ & $6.86 \pm 0.35 \mathrm{a}$ & $49.83 \pm 2.41 \mathrm{a}$ & $7.16 \pm 0.46 \mathrm{~d}$ & ND & 311.52 \\
\hline 5 & $108.43 \pm 5.18 \mathrm{a}$ & $14.94 \pm 0.95 \mathrm{c}$ & $22.45 \pm 1.50 \mathrm{c}$ & $11.21 \pm 0.61 \mathrm{c}$ & $6.82 \pm 0.35 \mathrm{ab}$ & $15.07 \pm 0.75 b$ & $10.17 \pm 0.51 \mathrm{c}$ & ND & 189.09 \\
\hline 10 & $10.91 \pm 1.03 \mathrm{c}$ & $18.89 \pm 5.21 \mathrm{~b}$ & $255.28 \pm 14.22 \mathrm{a}$ & $20.37 \pm 1.40 \mathrm{~b}$ & $4.6 \pm 0.29 \mathrm{~d}$ & $13.19 \pm 0.65 \mathrm{c}$ & $14.85 \pm 0.99 \mathrm{a}$ & ND & 338.09 \\
\hline 15 & $3.75 \pm 0.26 \mathrm{Cd}$ & $14.5 \pm 0.96 \mathrm{Cc}$ & $23.60 \pm 1.80 \mathrm{Cc}$ & $2.08 \pm 0.07 \mathrm{Cd}$ & $5.92 \pm 0.34 \mathrm{Bc}$ & $11.77 \pm 1.46 \mathrm{Bc}$ & $13.39 \pm 0.97 \mathrm{Aab}$ & $2.48 \pm 0.71$ & 77.50 \\
\hline \multicolumn{10}{|l|}{ Grey sufu } \\
\hline 0 & $196.07 \pm 10.56 \mathrm{a}$ & $30.60 \pm 2.66 \mathrm{c}$ & $195.67 \pm 11.62 d$ & $298.33 \pm 16.97 \mathrm{a}$ & $49.51 \pm 2.50 \mathrm{a}$ & $125.37 \pm 6.10 \mathrm{a}$ & $13.21 \pm 0.94 \mathrm{a}$ & ND & 603.10 \\
\hline 5 & $112.45 \pm 5.44 \mathrm{c}$ & $22.64 \pm 0.87 \mathrm{~d}$ & $343.16 \pm 15.56 \mathrm{c}$ & $201.51 \pm 13.99 \mathrm{c}$ & $36.10 \pm 1.31 \mathrm{~b}$ & $6.41 \pm 0.37 \mathrm{~d}$ & $12.22 \pm 0.72 \mathrm{ac}$ & ND & 734.86 \\
\hline 10 & $145.72 \pm 8.29 \mathrm{~b}$ & $83.58 \pm 5.17 \mathrm{a}$ & $522.04 \pm 31.24 \mathrm{a}$ & $259.35 \pm 10.68 b$ & $8.30 \pm 0.42 c$ & $12.27 \pm 0.46 \mathrm{~b}$ & $12.8 \pm 0.99 \mathrm{ab}$ & ND & 1044.06 \\
\hline 15 & $103.88 \pm 5.88 \mathrm{Bd}$ & $34.12 \pm 2.4 \mathrm{Bb}$ & $415.08 \pm 24.92 \mathrm{Ab}$ & $195.7 \pm 9.95 \mathrm{Ad}$ & $9.96 \pm 0.46 \mathrm{Ac}$ & $12.08 \pm 0.71 \mathrm{Bbc}$ & $10.69 \pm 0.64 \mathrm{Ac}$ & ND & 781.51 \\
\hline
\end{tabular}
Biogenic amines content is expressed in $\mathrm{mg} \mathrm{kg}^{-1}($ mean \pm SD).
"a-d" Different superscripts in the same column indicate significant statistical differences $(\mathrm{p}<0.05)$ in the same type of sample according to the Tukey's multiple range tests.

"A-C" Different superscripts in the same column indicate significant statistical differences $(\mathrm{p}<0.05)$ in the different type of sample stored for 15 days according to the Tukey's multiple range tests.

Supplementary Table S4: Evolution of biogenic amine concentrations in the three types of sufu at $35^{\circ} \mathrm{C}$.

\begin{tabular}{|c|c|c|c|c|c|c|c|c|c|}
\hline \multirow{2}{*}{$\begin{array}{l}\text { Storage } \\
\text { time (days) }\end{array}$} & \multicolumn{9}{|c|}{ Biogenic amines $\left(\mathrm{mg} \mathrm{kg}^{-1}\right)$} \\
\hline & PUT & $\mathrm{CAD}$ & HIS & TYR & PHE & TRY & SPD & SPM & TOTALS \\
\hline \multicolumn{10}{|l|}{ White sufu } \\
\hline 0 & $42.20 \pm 1.31 \mathrm{~d}$ & $38.43 \pm 3.96 b c$ & $158.17 \pm 10.00 \mathrm{~b}$ & $146.41 \pm 8.02 \mathrm{a}$ & $8.95 \pm 0.45 \mathrm{~d}$ & $10.42 \pm 0.45 \mathrm{~d}$ & $14.91 \pm 0.85 b$ & ND & 419.61 \\
\hline 5 & $144.48 \pm 10.85 a$ & $28.93 \pm 1.25 \mathrm{~d}$ & $146.78 \pm 11.11 \mathrm{~d}$ & $121.25 \pm 7.48 \mathrm{c}$ & $17.72 \pm 1.11 \mathrm{abc}$ & $23.74 \pm 1.20 \mathrm{c}$ & $12.81 \pm 1.38 \mathrm{bc}$ & ND & 495.71 \\
\hline 10 & $97.52 \pm 10.19 b$ & $38.76 \pm 2.75 b$ & $287.6 \pm 16.14 \mathrm{a}$ & $135.95 \pm 9.27 b$ & $17.69 \pm 1.81 \mathrm{a}$ & $35.3 \pm 3.44 \mathrm{~b}$ & $19.64 \pm 1.13 \mathrm{a}$ & ND & 632.44 \\
\hline 15 & $73.78 \pm 8.87 \mathrm{Bc}$ & $50.15 \pm 3.57 \mathrm{Aa}$ & $153.72 \pm 13.11 \mathrm{Bc}$ & $109.37 \pm 8.66 \mathrm{Bd}$ & $18.17 \pm 3.42 \mathrm{Ba}$ & $52.73 \pm 3.13 \mathrm{Ba}$ & $8.21 \pm 0.67 \mathrm{Bd}$ & ND & 466.12 \\
\hline \multicolumn{10}{|l|}{ Red sufu } \\
\hline 0 & $20.07 \pm 1.45 \mathrm{a}$ & $24.11 \pm 2.41 b c$ & $50.96 \pm 5.82 \mathrm{c}$ & $34.46 \pm 3.76 \mathrm{a}$ & $6.86 \pm 0.75 \mathrm{a}$ & $49.83 \pm 2.41 \mathrm{a}$ & $7.16 \pm 0.46 \mathrm{~b}$ & ND & 311.52 \\
\hline 5 & $4.62 \pm 0.24 \mathrm{~d}$ & $11.44 \pm 0.69 \mathrm{~d}$ & $4.53 \pm 0.55 \mathrm{~d}$ & $0.73 \pm 0.01 b c$ & $4.63 \pm 0.34 c$ & $8.87 \pm 0.66 c$ & $11.25 \pm 0.53 \mathrm{a}$ & ND & 46.07 \\
\hline 10 & $6.71 \pm 0.35 b$ & $30.08 \pm 1.77 \mathrm{a}$ & $258.64 \pm 13.74 a$ & $2.86 \pm 0.35 b$ & $6.76 \pm 0.72 \mathrm{ab}$ & $9.18 \pm 0.55 c$ & $0.83 \pm 0.06$ & ND & 315.06 \\
\hline 15 & $4.72 \pm 0.24 \mathrm{Cc}$ & $25.91 \pm 2.26 \mathrm{Cb}$ & $107.68 \pm 8.71 \mathrm{Cb}$ & $1.28 \pm 0.07 \mathrm{Cbc}$ & $5.41 \pm 0.42 \mathrm{Cc}$ & $18.95 \pm 0.95 \mathrm{Cb}$ & $3.24 \pm 0.36 \mathrm{Cc}$ & ND & 167.21 \\
\hline \multicolumn{10}{|l|}{ Grey sufu } \\
\hline 0 & $196.07 \pm 15.56 \mathrm{a}$ & $30.60 \pm 2.66 \mathrm{~d}$ & $195.67 \pm 18.62 d$ & $298.33 \pm 16.97 \mathrm{a}$ & $49.51 \pm 3.50 \mathrm{a}$ & $125.37 \pm 6.10 \mathrm{a}$ & $13.21 \pm 0.72 \mathrm{c}$ & ND & 603.1 \\
\hline 5 & $69.59 \pm 6.64 d$ & $49.68 \pm 4.72 \mathrm{a}$ & $317.22 \pm 17.11 \mathrm{c}$ & $173.46 \pm 13.23 \mathrm{~d}$ & $18.55 \pm 0.99 \mathrm{~d}$ & $5.6 \pm 0.21 \mathrm{c}$ & $9.63 \pm 0.71 \mathrm{~d}$ & ND & 643.72 \\
\hline 10 & $121.87 \pm 18.36 \mathrm{~b}$ & $42.98 \pm 5.78 b$ & $446.9 \pm 21.27 \mathrm{a}$ & $246.25 \pm 12.35 b c$ & $34.79 \pm 2.96 \mathrm{~b}$ & $6.88 \pm 0.41 \mathrm{c}$ & $84.31 \pm 6.37 \mathrm{a}$ & ND & 983.99 \\
\hline 15 & $106.47 \pm 9.49 \mathrm{Ac}$ & $36.08 \pm 0.68 \mathrm{Bc}$ & $421.61 \pm 20.96 \mathrm{Ab}$ & $249.5 \pm 15.38 \mathrm{Ab}$ & $34.26 \pm 3.35 \mathrm{Abc}$ & $91.43 \pm 7.54 \mathrm{Ab}$ & $46.32 \pm 4.6 \mathrm{Ab}$ & ND & 985.65 \\
\hline
\end{tabular}

Biogenic amines content is expressed in $\mathrm{mg} \mathrm{kg}^{-1}$ (mean $\pm \mathrm{SD}$ ).

"a- $d$ " Different superscripts in the same column indicate significant statistical differences $(p<0.05)$ in the same type of sample according to the Tukey's multiple range tests.

"A-C" Different superscripts in the same column indicate significant statistical differences $(\mathrm{p}<0.05)$ in the different type of sample stored for 15 days according to the Tukey's multiple range tests. 
JingJing Liang et al. / American Journal of Biochemistry and Biotechnology 2018, 14 (4): 285.297 DOI: 10.3844/ajbbsp.2018.285.297

Supplementary Table S5: Predicted the content of total biogenic amines in the next $20-40$ days by artificial neural networks. Biogenic amines content is expressed in mg $\mathrm{kg}^{-1}$

\begin{tabular}{|c|c|c|c|c|c|c|c|c|c|c|c|c|}
\hline \multirow{2}{*}{$\begin{array}{l}\text { Storage } \\
\text { time(days) }\end{array}$} & \multicolumn{3}{|l|}{$4^{\circ} \mathrm{C}$} & \multicolumn{3}{|l|}{$15^{\circ} \mathrm{C}$} & \multicolumn{3}{|l|}{$25^{\circ} \mathrm{C}$} & \multicolumn{3}{|l|}{$35^{\circ} \mathrm{C}$} \\
\hline & White sufu & Red sufu & Grey sufu & White sufu & Red sufu & Grey sufu & White sufu & Red sufu & Grey sufu & White sufu & Red sufu & Grey sufu \\
\hline 20 & 634.24 & 409.33 & 878.76 & 556.98 & 376.88 & 890.76 & 743.64 & 876.54 & 903.45 & 789.34 & 247.34 & 523.76 \\
\hline 25 & 711.72 & 476.54 & 1006.65 & 998.34 & 455.09 & 906.11 & 994.22 & 1022.47 & 1126.33 & 985.37 & 487.45 & 578.32 \\
\hline 30 & 823.35 & 656.65 & 1078.51 & 754.77 & 568.98 & 1062.83 & 862.43 & 1065.24 & 1324.24 & 1123.84 & 589.65 & 687.32 \\
\hline 35 & 845.71 & 665.25 & 1154.12 & 878.42 & 976.54 & 1149.61 & 935.33 & 1189.40 & 1053.32 & 1222.87 & 765.99 & 712.22 \\
\hline 40 & 876.34 & 805.64 & 1223.87 & 966.43 & 983.83 & 1042.95 & 988.65 & 922.32 & 1032.43 & 1015.35 & 996.76 & 1174.43 \\
\hline
\end{tabular}

